\title{
Redesigning for Student Success: Cultivating Communities of Practice in a Higher Education Classroom
}

\begin{abstract}
Launa Gauthier ${ }^{1}$
Abstract: In this paper, I discuss the process of redesigning and teaching a mandatory, academic skill building course for students on academic probation at Mount Saint Vincent University (MSVU) in Atlantic Canada. The rationale for redesigning the course was to offer an alternative curricular framework, including instructional approaches, to course instructors who taught a modular-based curriculum. The original course was designed to focus on improving students' individual self-efficacy and motivation for academic success; however, the social and relational nature of learning was not articulated as an underpinning theory in the curriculum. In the new curriculum, I draw on both Etienne Wenger's (1998) notion of communities of practice as sites for learning and Howe and Strauss' (2000; 2007) work on generational analysis as theoretical frameworks. Furthermore, I incorporate Wenger, McDermott, and Snyder's (2002) design principles for cultivating communities of practice as a framework for translating theory into practice. The initial information that I collected from students, instructors, and a thorough review of the original curriculum led to the main inquiry question: How can a curriculum, centred on building community in the classroom, help students to cultivate meaningful learning experiences that take learning beyond a "fake it "til you make it" mentality? This question guided the curricular design process and also my experiences teaching the course at MSVU during the Fall semester of 2012.
\end{abstract}

Keywords: course design, communities of practice, social learning, student success, millennial generation, higher education, teaching.

In recent decades, student retention and success has increasingly become a leading concern in universities in North America (Albert, 2010). Studies show that low student retention has many personal and financial repercussions for students and parents, potential loss of skills and knowledge for society, and both financial and reputational implications for higher education institutions (Yorke \& Longden, 2004). The increase in services designed to promote and support overall student experience and academic success are indicators that institutions are seeking to mediate these risks. For example, many universities in North America adhere to four areas for supporting student retention: building awareness, accessibility services, academic supports, and transition services (Moxley, Najor-Durack, \& Dumbrigue, 2013). Expanding counselling assistance and creating academic support programs, which include courses that students can take to build their academic skills and improve their Grade Point Averages (GPA), are examples of such services.

In this paper, I discuss the process of designing a course called, Student Success: A Course for Personal and Academic Development. This course was written as an alternative version of a course called the Student Success Course (SSC) - a mandatory, academic skill building course for

\footnotetext{
${ }^{1}$ Faculty of Education and Centre for Teaching and Learning, Queen's University, 511 Union St., Kingston, ON K7M 5R7, launa.gauthier@queensu.ca
} 
students on academic probation - at Mount Saint Vincent University (MSVU), located in Atlantic Canada. I explain how the new curriculum was written using both Etienne Wenger's (1998) notion of communities of practice as sites for learning and Howe and Strauss' $(2000$; 2007) work on generational analysis as theoretical frameworks. Furthermore, I discuss how I incorporated Wenger, McDermott, and Snyder's (2002) principles for cultivating communities of practice as a curriculum design framework for translating theory into practice.

The aim of this paper is to provide higher education instructors and instructional designers with an example of a theory-informed curricular framework and suggestions for implementing such a design in practice. Throughout the paper, I draw on my own experiences of teaching the course in order to highlight pertinent aspects of how I enacted the curriculum in the classroom. I provide a starting point for instructors to consider conceptualizing a holistic framework for course design by designing for classroom communities of practice (Wenger, 1998) as contexts for cultivating transformative learning experiences with students. According to Wenger (2006), a community of practice exists when a group of people "engage in a process of collective learning in a shared domain of human endeavour... [and they] share a concern or a passion for something they do and learn how to do it better as they interact regularly" (para. 4). Secondly, the discussion in this paper is meant to act as an exemplar of a shift in the discourse on teaching and learning in higher education. More specifically, this shift is one that honours the emergent nature of both teaching and learning as a dialectal activity that can be supported when instructors cultivate communities of practice in higher education classrooms.

\section{A Context for Redesign}

The original SSC at MSVU was developed in 1999 by individuals working in Student Affairs as a retention effort aimed at supporting students who were at-risk of dismissal from the University. Typically, Student Affairs personnel and part-time instructors were hired to teach the SSC. In 2012, the average student enrollment at MSVU was about four thousand students. In addition, approximately one-hundred of these students were on academic probation and enrolled in the SSC for the first semester of their second year of university. At the time, the SSC had been divided into five sections with a cap of twenty students in each class. According to a study by Bowering and Merritt (2006), students who enrolled in this class shared a collection of similar characteristics. Students were on academic probation (they had a cumulative grade point average (GPA) less than 1.7 and greater than 1.0); they were under pressure to increase their GPA and had been experiencing a lot of stress; they were diverse in terms of cultural, socioeconomic backgrounds, upbringing, and learning histories; they were mostly in their second year of university and between the ages of 17 to 25; and, most students were typically enrolled in 2-3 other courses alongside of the SSC.

\section{Rational for Redesigning the SSC}

The rationale for redesigning the SSC was to offer an alternative curricular framework, including instructional approaches, to SSC instructors for meeting the learning needs of their undergraduate students who were on academic probation. One of the primary aims of the course, in addition to academic skill building, was for students to develop a sense of responsibility for their own learning. With this goal in mind, the course was initially designed through a predominantly cognitive 
perspective founded on theories of personal self-efficacy and motivation. Given this standpoint, each of the separate course modules were purposefully designed to focus on the individual student with the intention of improving their academic performance. While clearly evident and supported in the classroom environment, the social and relational nature of learning was not articulated in the theoretical underpinning of the original SSC curriculum. The need for this to be articulated as part of the curriculum seemed evident in order to maintain consistency in how and what was being taught but also to ensure the curriculum accurately reflected the social realities of the SSC learning environments.

From a curricular standpoint, the SSC was organized within a scientific curricular framework (see for example, Tyler, 1950). Within this framework, learning objectives, curricular content and resources can be easily predetermined and coherently organized. In addition, learning can be sequenced in a logical, step-by-step manner which can help students to grasp a clear understanding of the subject matter of their disciplines (Sowell, 2005). Many instructors find comfort in the systematic approaches to teaching and learning content that are espoused in such an approach to curriculum design. However, I was curious as to whether or not the linear instructional and learning processes that are predisposed within this curricular framework were conducive to helping students to claim ownership and discover intrinsic value in what they were learning (Wenger, McDermott, \& Snyder, 2002) and potentially be transformed by their experiences. Research found that the instruction that students received in the SSC was effective in the short term in promoting academic success; however, long term effects of the course on students' learning and personal development have yet to be studied (Bowering \& Merritt, 2006; Fancey, 2000). Ultimately, I recognized the potential for designing a curricular framework that supported open and safe contexts where students felt trust, respect, and freedom to explore ideas together (Cranton, 2002). In other words, a purpose for the new curriculum was to be more explicate in theory and in practice about showing how to support opportunities for students to be potentially transformed through their learning with others.

\section{Collecting Information and Course Planning}

\section{Considering Stakeholders’ Interests}

From the initial planning stages of redesigning this course, I consulted the adult education literature on curriculum and program planning for adult learners. Specifically, I ascribed to Wilson and Cervero's (1996; 1997) argument that any stakeholders who may be affected by a program (or a course) should be involved in discussing what factors and features of the program content are important. As such, Wilson and Cervero (1997) describe program planning as a social activity in which planners negotiate personal and organizational interests to construct educational programs for adults. For example, I had conversations with students, instructors, and the course coordinator in order to gain their perspectives on the situational factors that influence course design. Some of these factors included the pressures of the accountability and retention paradigms at the university and the influence of the constraints of academic probation on students themselves. By engaging in conversations with each stakeholder group, I also gained insight into whose perspective and values had been used to determine the effectiveness, efficiency, relevance, and innovativeness of the original course and whose perspective and values may have been unknowingly disregarded. I used the information from each of these conversations as a form of gap analysis to support the course 
design. Participants' words were represented in the common themes that I derived from conversations with them but individual quotes were not directly incorporated into the final curriculum document.

\section{Information Collection}

I collected information initially by speaking with all six course instructors and the course coordinator at the end of the first semester of the 2011-2012 academic year. I collaborated with these individuals in order to get a sense of the purpose of the sequence of course topics, to learn about the topics and instructional strategies by which students were most engaged, and to elicit their opinions on what areas of the course they felt needed improvement. Next, I visited four classes in December of 2011 that were following the original SSC curriculum. I engaged in conversations with students in the classes about the nature of the course and their experiences in the class. Table 1 outlines a series of questions that I used to gain an understanding both of students' perceptions of the SSC and of their learning experiences in the course.

\section{Table 1. List of questions for students}

1. How do you want to learn? Tell me about whether you feel there are opportunities for you to learn this way, in university?

2. Knowing that all professors have different ways of teaching, designing courses, and different views on student learning, how do you feel this affects you as a student? What are the implications for your learning in these situations?

3. What does "success" mean to you? How did you learn that this is what success means?

4. What definition of success do you feel is promoted at your university?

5. Is there a difference between success in life and success in university? Please explain.

6. How much input did you have on the course content? Did you feel there was room to change the course plan at all?

7. Which topics did you find the most helpful to your learning and development as a student?

8. Which course topics and content were most relevant to you? Please explain.

9. Do you feel better prepared for your other university courses after finishing the student success course? Please explain.

A number of strong themes emerged from conversations with students in the SSC. First, it was clear that students felt a positive rapport with the instructor. Many students indicated that the instructor established a bond with them through demonstrating care, understanding, flexibility, and by being available to them for individual consultations. Next, students commented on the sense of mutuality that developed in the group as the semester progressed. Numerous students attributed this to the fact that they got to know other individuals in the class who were in similar academic situations and, in some cases, comparable social and economic circumstances. Finally, students noted a direct connection between course content being relevant to their lives and their increased motivation for improving their academic and interpersonal skills. Some students' responses indicated that what they learned in the course had contributed to significant changes in their personal lives and academic success while, for other students, the course did not have such an effect. However, the modular, predominately cognitive-focus of the course curriculum did not Journal of the Scholarship of Teaching and Learning, Vol. 16, No. 2, April 2016.

Josotl.Indiana.edu 
reflect the kinds of transformations in attitude, behaviours, and beliefs that seemed to be articulated by students and their instructors. In the reality of the classroom, each of these transformations were supported through shared bonds, common understanding, and mutual support in the group. In considering the above themes within the framework of both theories that undergird this course, it was apparent that many of the learning experiences that these themes represent could be enhanced through cultivating communities of practice in the classroom.

Finally, I reviewed the original SSC curriculum document, the online supplemental content and the suggested instructional strategies. Specifically, I looked for key aspects of the content that could be retained in the new version of the course (e.g. particular course topics, activities, descriptions in the course syllabus) and language that could be changed to fit the new course design (e.g. changing "module 1" to "week 1", or using phrases such as "students will have opportunities to . ..” instead of the more prescriptive "students will learn X"). The purpose at this stage was to improve the general flow of the curriculum by shifting the language used to describe teaching and learning processes in a way that honoured the emergent nature of communities of practice in the classroom.

To organize the above information, I created a planning matrix centered on the theoretical frameworks for the course - communities of practice (Wenger, 1998) and generational analysis theory (Howe \&Strauss, 2000; 2007). In the matrix, I recorded information regarding the beneficial aspects of the original course, such as a particular course topic or instructional strategy, and considered ways of blending these with ideas I had for the new curriculum. Furthermore, the matrix allowed for easy identification of where the gaps were in language, content, instructional methods, and resources.

The combination of the above information prompted the following questions that guided the curriculum design process: 1 ) How is the current SSC curriculum conducive to helping students to find intrinsic value in what they are learning and, potentially, be transformed by their learning experiences? 2) How can a curriculum, centred on building community in the classroom, help students to cultivate meaningful learning experiences that take learning beyond a "fake it "til you make it" mentality? This last question was especially pertinent to the redesign process given that the SSC was (and still is) a pass/fail course where student achievement is heavily contingent upon attendance and completion of assignments.

\section{Opportunities versus Prescriptions for Learning}

Wenger (1998) argues that, in a community of practice, learning emerges from the interactions people have during the pursuit of a joint practice and as they negotiate the meaningfulness of what they are doing. The main purpose of cultivating a class community of practice is to bring about the class community's own internal direction, character, and energy. To try to predetermine too many learning outcomes or how learning will emerge and evolve would be contradictory to this approach. In planning the new course, I purposefully changed the language to describe learning from prescribing what students will learn to what opportunities students will have to learn. Table 2 outlines the learning opportunities that students had the chance to experience in the course.

\section{Table 2. Student learning opportunities}

Students will have opportunities to:

Journal of the Scholarship of Teaching and Learning, Vol. 16, No. 2, April 2016. Josotl.Indiana.edu 


\begin{tabular}{|ll|}
\hline 1. & Improve academic skills, acquire new skills and identify academic needs \\
\hline 2. & Connect with a community of learners and share ideas and resources to help each other learn \\
\hline 3. & Become self-regulated academic learners ${ }^{2}$ \\
\hline 4. & Use methods of critical reflection to examine assumptions, beliefs, and values about learning \\
\hline $\begin{array}{l}\text { 5. } \\
\text { Think critically about personal learning histories and share experiences and stories related } \\
\text { to learning }\end{array}$ \\
\hline 6. & Make informed academic decisions that realistically match goals and capabilities \\
\hline 7. & Develop and improve problem-solving and negotiation skills \\
\hline 8. & Increase confidence and uncover motivations for learning \\
\hline 9. & Examine psychological variables that impact academic progress \\
\hline
\end{tabular}

Taken together, the above opportunities for learning augments systematic learning outcomes that prescribe what students will learn and are typically hard to predict because they are difficult to determine ahead of time. Part of the magic behind fostering communities of practice in the classroom is witnessing the various depths of learning that emerge from purposeful, social interactions and relationship building among class participants.

\section{Theoretical Framework}

The curriculum for this course was based on a combination of social learning theory, generational analysis theory, and design principles. I used Howe and Strauss' (2000; 2007) generational model to describe the characteristics of the Millennial Generation - the term that broadly categorizes students in the course. In addition, Wenger's (1998) communities of practice theory provided a basis for communicating how student learning can be both situational and relational in nature. Finally, Wenger, McDermott, and Snyder's (2002) seven principles for design for communities of practice framed the content of the curriculum - the weekly course topics, instructional methods, learning activities, assessment strategies, and additional resources.

\section{Millennial Students}

Over a number of years, Neil Howe and William Strauss have tracked, surveyed, and studied the Millennial Generation - the individuals born between 1982 and 2000 who now attend postsecondary institutions. The authors' publications, Millennials Rising: The Next Great Generation (2000), and Millennials go to College (2007) elaborate on the impact that this collegiate generation has had on higher education in terms of curriculum planning, teaching, recruitment and admissions strategies, campus life, and understanding of student learning. Howe and Strauss (2000; 2007) describe seven core traits of Millennial students as: special, sheltered, confident, team-oriented, conventional, pressured, and achieving. The authors suggest that Millennials have been perceived as special or unique from the time of birth; they are often sheltered and protected primarily by their parents in ways that previous generations were not; they adopt conventional/traditional

$2 \quad$ Self-regulated academic learners are metcognitively, motivationally, and behaviourally active participants in their own learning; they are aware of when they possess a skill and when they do not; they recognize obstacles to their own learning and often find a way to succeed; and, often accept greater responsibility for their own academic achievement (Zimmerman, 1989).

Journal of the Scholarship of Teaching and Learning, Vol. 16, No. 2, April 2016.

Josotl.Indiana.edu 
perspectives; they feel more pressure to succeed in today's society than previous generations; they have an affinity toward teamwork as opposed to working individually; they are often considered as a "group" and thus, achievement is marked by their ability to keep pace with the group (hence their focus on achieving high grades); and, they are fueled by a sense of confidence and empowerment that surpasses many previous generations.

There is a growing body of literature in higher education that focuses on teaching Millennial students. This work suggests that instructors move away from only teaching through traditional lectures to using more instructional practices that incorporate the seven core traits (Dede, 2005; Howe \& Strauss, 2007). For example, researchers suggested that undergraduate students today benefit from incorporating interactive technology, active learning, collaborative learning, content that is relevant to their lives, flexibility in grading, clarity of guidelines and expectations, frequent and immediate feedback on work and progress, and time on task (Dede, 2005; Howe \& Strauss 2000; Oblinger, 2003; Skiba \& Barton, 2006; Wilson, 2004). I incorporated some of these methods for working with Millennial students into the new course in an effort to include the seven traits outlined by Howe and Strauss (2000, 2007) and to help students to develop a sense of ownership and find value in what they were learning. For example, students had opportunities to engage in collaborative activities such as group presentations and team building exercises, use online blogs to disseminate their work and share resources, receive ongoing instructor and peer feedback, and offer input into class activities, content, and guest speakers.

\section{Situated Learning in Communities of Practice}

The course curriculum was also written with attention to Lave and Wenger's (1991) theory of situated learning within communities of practice. Communities of practice are typically "formed by people who engage in a process of collective learning in a shared domain of human endeavour... [and they] share a concern or a passion for something they do and learn how to do it better as they interact regularly” (Wenger, 2006, para. 4). Within a community of practice people also develop, negotiate, and share personal ways of understanding the world; they experience a form of social learning. Such social interaction forms the basis of a common bond that helps to establish a group identity and a sense of shared value to the learning that occurs within the group.

Central to situated learning is a process that Lave and Wenger (1991) refer to as legitimate peripheral participation, whereby individuals participate, to varying degrees, in a shared practice that is situated within their community of practice. In theory, an individual's goal in a community of practice is to move from the periphery of the community toward full participation. For instance, in this course, as students gradually gained confidence in their abilities and improved their academic and social skills, they became more comfortable and involved in learning activities. In some cases, certain students eventually assumed leadership roles in the class community of practice and acted as mentors to other students. Moreover, as the semester progressed, I witnessed an increase in student collaboration outside of class for study sessions, students checking in on one another on their blogs, and students making the effort to hold each other accountable for personal and group goals.

Participation within communities of practice is guided by reification-giving form to experience-of objects or concepts that concretely represent the practice (e.g. tools, symbols, stories, documents) and thus, the community of practice itself. For example, in the class, students developed tools and resources that helped them to develop and refine their academic skills.

Journal of the Scholarship of Teaching and Learning, Vol. 16, No. 2, April 2016. Josotl.Indiana.edu 
Specifically, students created course blogs that they used to communicate with me and the other students in the class. Students posted written reflections, reactions to other students' blogs, and responses to conversations with various guest speakers that we invited to the class. Students' blogs were spaces unique to each individual; however, each blog was linked to the other class blogs. In this way, students' blogs acted as a visual representation of the shared identity that we cultivated in the class community of practice.

\section{Three Key Elements of a Community of Practice}

Wenger (1998) identifies three key elements for learning in a community of practice that give meaning to the processes of participation and reification. He notes that mutual engagement, joint enterprise (or domain), and a shared repertoire are the key determinants of communities as sites for learning. Mutual engagement is the established norms and collaborative relationships that members of a community of practice create through participation in the community; it is the emerging pattern of actions that occur as a group interacts regularly and for a particular purpose. The relationships that people cultivate are the ties that bind the members of the community together as a social entity. For instance, in this course, as students interacted with one another they began to value certain ways of doing things together and a group flow emerged. Wenger suggests that a predominant benefit of working collaboratively is that learners form a common bond centred on a shared understanding of the similarities that tie them together as a group (mutual engagement). This bond looks, feels, and is enacted differently in every group because group dynamics are uniquely configured depending upon the individual members and their personal learning histories. An additional advantage to community involvement for students can be that they generate a sense of ownership for their learning along with feelings of belonging and commitment to the group (Handley, Sturdy, Fincham, \& Clark, 2006). Wenger (1998) adds that this sense of mutual engagement is an ideal context for the creation of knowledge. He explains that individuals can explore new ideas (even radical ideas) without feeling intimidated or embarrassed because "there is a strong bond of communal competence along with a deep respect for the particularity of experience" (p. 214). Secondly, as community members interact they form a shared understanding, or joint enterprise, of how they are connected together. This joint enterprise is constantly negotiated and re-negotiated by members throughout the life of the community and is sometimes referred to as the domain of the community. Students in the course had some similar key characteristics in their learning histories and current personal situations. For the most part, students established a group identity around a shared understanding of knowing what it is like to be in the situation they were in and also the shared desire to improve or change their personal and academic circumstances. Finally, as a result of the pursuit of joint enterprise over time, the community develops a shared repertoire, or set of common resources, as mentioned in the previous description of the reification process.

\section{Cultivating a Community of Practice in the Classroom}

In redesigning the SSC, I established the three key determinants for learning in a community of practice - mutual engagement, joint enterprise, and shared repertoire-by using a specific design framework. I used Wenger, McDermott, and Snyder's (2002) seven principles for supporting learning within communities of practice paired with Howe and Strauss' (2000; 2007) descriptions

Journal of the Scholarship of Teaching and Learning, Vol. 16, No. 2, April 2016. Josotl.Indiana.edu 
of the characteristics of Millennial students. The curriculum was purposefully woven together with the following seven principles of design:

1. Design for Evolution.

2. Open dialogue between inside and outside perspectives.

3. Invite different levels of participation.

4. Develop both public and private community spaces to network and share information.

5. Focus on value.

6. Combine familiarity and excitement.

7. Create a rhythm for the community. ～(Wenger, McDermott, \& Snyder, 2002)

Some of these principles were easy to implement in the beginning stages of curriculum design. For instance, I planned for students to create blogs in order to provide them with both public and private community spaces to network and share information and for people to interact outside of the classroom (principles 3 and 4). Students in the class interacted in these spaces at their leisure but their online activity also enabled a continuous development of a group identity outside of the classroom. I cultivated other principles throughout the course as the semester progressed and the class community of practice continued to evolve. For instance, I invited various guest speakers or "experts" to lead skill- building workshops on topics such as the fundamentals of academic writing and reading critically. The purpose of these activities was to invite outside participation and build networks with other communities of practice on a regular basis (principle 2). As the needs of the group emerged from week to week, we selected individual speakers to invite into the class and identified additional content and learning strategies that we thought would enhance learning (principles 1 and 5). Evidently, this also contributed to keeping the content fresh and relevant and added and element of excitement to the course (principle 6). Finally, in this particular class, the ongoing interplay between principles 1-6 allowed a group "rhythm" or flow to emerge (principle 7). It is important to note that the instructor plays a key role in maintaining the ebb and flow of the community through balancing the interplay of these seven principles and by paying close attention as the needs of the group change and continue to emerge.

\section{Supporting a Community of Practice in the Classroom}

“The most important factor in the community’s success is the vitality of its leadership” (Wenger, McDermott, \& Snyder, 2002, p.80).

Cultivating communities of practice within higher education classrooms, requires an understanding and appreciation for the social, situated nature of learning (see Lave, 2009; Lave \& Wenger, 1991; Wenger, 2009). This approach is embedded in the assumption that collective and individual learning occurs as people engage in a shared endeavour and interact with one another to learn in various ways. In a classroom community of practice, students and instructors reflect on, negotiate, and redesign aspects of the class according to the needs and interests that emerge from their personal experiences and shared histories. However, if learning is assumed to be emergent from individual and social processes in the classroom then it implies that instructional processes that provoke learning have to be somewhat organic as well.

While there is not a perfect formula for best practices or set of prescribed objectives for supporting emergent learning in a group context, there certainly are practices that work well. For Journal of the Scholarship of Teaching and Learning, Vol. 16, No. 2, April 2016. Josotl.Indiana.edu 
example, instructors can invite students to take part in class discussions and to direct the ebb and flow of conversation, they can offer students freedom and choice on class assignments, and they can set up structures that give students opportunities to engage in conversation with each other outside of class (through the use of technology such as email, blogs, and wikis). However, given that the dynamics, the individuals, and the physical environment of each class will differ considerably, instructors need to choose and/or develop suitable instructional practices on an individual, class-by-class basis. Stemming from the experience of redesigning and teaching this course, I suggest that instructors have to work on building "best insights" during and after every class that they teach. After all, learning about teaching is a process of discovery; it is one that involves learning from what is happening in real time, in the classroom, with students and their learning.

By supporting the evolution of communities of practice in the classroom, instructors can simultaneously create spaces for potential transformative learning. Significant scholarly work on teaching and learning in adult education and higher education stress some common characteristics of instructors who seek to support transformative learning. Some of these qualities include: modeling critical reflection; promoting experiential learning and collaboration; valuing learning histories (self and students); empowering students to question their assumptions, beliefs and values; inviting student input into course design; and, having a good understanding of group dynamics (see for example, Brookfield, 2006; Cranton, 2006; Mezirow \& Taylor, 2009; Taylor, 2000). Ultimately, setting the stage for transformation requires an openness to the possibility that learning will likely emerge from a variety of interactions - student to student; student to instructor; and, student to curriculum content.

\section{Conclusions}

The implications for this course redesign reach beyond the local level of student retention efforts at MSVU and academic success courses themselves. Thinking about the various theoretical and design aspects involved in cultivating communities of practice with students can inspire instructors and instructional designers to consider how they frame curriculum in courses in higher education. Specifically, the theory and suggestions for curriculum design in this paper act as a guide for conceptualizing and cultivating contexts for learning that are: a) supportive of learning that is applicable and meaningful to students; b) conducive to helping students to discover their own intrinsic motivation for continuous, lifelong learning; and c) potentially transformative. According Wenger (1998), to catalyze these learning processes, students need opportunities to participate in directing the internal direction of the course and to engage in learning both individually and as a group. Thus, the main goal of the redesigned course was to promote student-focused, participatory classes that left space for relevant content and opportunities for learning to emerge as students progressed through the course.

Much like what Wenger, McDermott, and Snyder (2002) suggest, I found that helping students to cultivate a sense of value as members of the class community contributed to their sense of ownership of their learning. In past work (Bogusz \& Gauthier, 2012), I have theorized that this helps to promote a sense of lifelong learning, which, can sometimes be a struggle in courses that are graded simply as pass or fail. I purposefully redesigned the original SSC from the relational perspective that individuals learn with, through, and from others. In this spirit, when I developed

Journal of the Scholarship of Teaching and Learning, Vol. 16, No. 2, April 2016. Josotl.Indiana.edu 
Student Success: A Course for Personal and Academic Development, I presented learning as a lifelong journey that is both individual and social and not simply a means to an end.

In the beginning of this paper, I pointed out that the rationale for redesigning the new curriculum for the SSC was to have the curriculum itself reflect the social, relational, and emergent nature of learning. This, I noted, was one of the limitations of the theoretical foundations of the original course curriculum. I situated the redesign process in theory from the literature and reported on putting theory into practice both in the curriculum design process and in my own classroom when I piloted the course. Moving forward, more research is needed to determine the effects and impact of the redesigned course over time and with various groups of students.

\section{Acknowledgements}

This work was supported by the Student Success Course coordinator, JoAnne Mills, in the Office of Student Experience at Mount Saint Vincent University, in Halifax, Canada.

\section{References}

Albert, S. (2010). The evolution of retention. Educational Solutions, 2010 (7), 16-17.

Bogusz, G. and Gauthier, L. (2012). Promoting lifelong learning in women's federal correctional programs: A communities of practice approach. In S. Brigham (Ed), Proceedings of the 31 National Conference of Canadian Association for the Study of Adult Education, 26-32.

Bowering, E. and Merritt, A. (2006). Evaluation of the MSVU Student Success Course. Retrieved October 10, 2011, from http://www.msvu.ca/site/media/msvu/eval2006.pdf

Brookfield, S. D. (2006). The skillful teacher: On technique, trust, and responsiveness in the classroom. San Francisco, CA: Jossey-Bass.

Cranton, P. A. (2002). Teaching for transformation. New Directions for Adult and Continuing Education, 2002 (93), 63-72.

Dede, C. (2005). Planning for "Neomillennial” learning styles: Implications for investments in technology and faculty. In D. Oblinger and J. Oblinger (Eds), Educating the Net Generation. (pp. 15.1-15.22). Washington, DC: Educause.

Fancey, P. (2000). Student Success Course: Evaluation results. Retrieved from http://www.msvu.ca/site/media/msvu/eval2000.pdf

Handley, K., Sturdy, A., Fincham, R. and Clark, T. (2006). Within and beyond communities of practice: Making sense of learning through participation, identity and practice. Journal of Management Studies, 43 (3), 641-653.

Howe, N. and Strauss, W. (2000). Millennials rising: The next great generation. Toronto, ON: Random House.

Journal of the Scholarship of Teaching and Learning, Vol. 16, No. 2, April 2016.

Josotl.Indiana.edu 
Howe, N. and Strauss, W. (2007). Millennials go to college. Great Falls, VA: LifeCourse Associates.

Lave, J. (2009). The practice of learning. In K. Illeris (Ed.), Contemporary Theories of Learning: Learning Theorists ... In Their Own Words, (pp. 200- 208), New York, NY: Routledge.

Lave, J. and Wenger, E. (1991). Situated learning: Legitimate peripheral participation. Cambridge, UK: Cambridge University Press.

Mezirow, J. and Taylor, E. (2009). Transformative learning in practice insights from community, workplace, and higher education. San Francisco, CA: Jossey-Bass.

Moxley, D., Najor-Durack, A. and Dumbrigue, C. (2013). Keeping students in higher education: Successful practices and strategies for retention. New York, NY: Routledge.

Oblinger, D. G. (2003). Boomers, gen-xers, and millennials: Understanding the "new students." EDUCAUSE Review, 38 (4), 36-40.

Skiba, D. and Barton, A. (2006). Adapting Your Teaching to Accommodate the Net Generation of Learners. OJIN: The Online Journal of Issues in Nursing, 11(2). Retrieved October, 11, 2012 http://www.nursingworld.org/MainMenuCategories/ANAMarketplace/ANAPeriodicals/OJIN/Ta bleofContents/Volume112006/No2May06/tpc30_416076.aspx

Sowell, E. J. (2005). Curriculum: An integrative introduction (3rd ed.). Upper Saddle River, NJ: Pearson Education.

Taylor, E. W. (2000). Fostering Mezirow's transformative learning theory in the adult education classroom: A critical review. The Canadian Journal for the Study of Adult Education, 14 (2), 128.

Tyler, R. W. (1950). Basic principles of curriculum and instruction. Chicago, IL: University of Chicago Press.

Wenger, E. C. (1998). Communities of practice: Learning, meaning, and identity. Cambridge, UK: Cambridge University Press.

Wenger, E. (2006, June). Communities of practice. Retrieved October 13, 2011, from http://www.ewenger.com/theory/index.htm

Wenger, E. C. (2009). A social theory of learning. In K. Illeris (Ed.), Contemporary Theories of Learning: Learning Theorists ... In Their Own Words, (pp. 209-218), New York, NY: Routledge

Wenger, E., McDermott, R. A. and Snyder, W. (2002). Cultivating communities of practice: A guide to managing knowledge. Boston, MA: Harvard Business Press.

Journal of the Scholarship of Teaching and Learning, Vol. 16, No. 2, April 2016.

Josotl.Indiana.edu 
Wilson, A. and Cervero, R. (1996). Learning from practice: Learning to see what matters in program planning. New Directions for Adult and Continuing Education, 1996 (69), 91-99.

Wilson, A. and Cervero, R. (1997). The song remains the same: The selective tradition of technical rationality in adult education program planning theory. International Journal of Lifelong Education, 16 (2), 84-108.

Wilson, M. E. (2004). Teaching, learning, and millennial students. New Directions for Student Services, 2004 (106), 59-71.

Yorke, M. and Longden, B. (2004). Retention and student success in higher education. Maidenhead, UK: Open University Press.

Zimmerman, B. J. (1989). A social cognitive view of self-regulated academic learning. Journal of Educational Psychology, 81(3), 329-339 